\title{
Antibacterial properties and toxicity from metallic nanomaterials [Corrigendum]
}

\author{
Vimbela GV, Ngo SM, Fraze C, Yang L, Stout DA. \\ Int J Nanomedicine. 2017;12:3941-3965.
}

Page 3943, Figure 1, the following text should be included in the Notes section:

Adapted by permission from Springer Nature. Springer, Journal of Nanoparticle Research. A review of the antibacterial effects of silver nanomaterials and potential implications for human health and the environment. Marambio-Jones C, Hoek EMV, 2010;12:1531-1551. Copyright (C) 2010. ${ }^{145}$
The figure is excluded from the CC-BY-NC license under which the article is published by Dove Medical Press.

Page 3965, References, a reference was excluded from the reference list, the missing reference is " 145 . Marambio-Jones C, Hoek EMV. A review of the antibacterial effects of silver nanomaterials and potential implications for human health and the environment. Journal of Nanoparticle Research. 2010;12:1531-1551”.
International Journal of Nanomedicine

\section{Publish your work in this journal}

The International Journal of Nanomedicine is an international, peerreviewed journal focusing on the application of nanotechnology in diagnostics, therapeutics, and drug delivery systems throughou the biomedical field. This journal is indexed on PubMed Central, MedLine, CAS, SciSearch $\AA$, Current Contents $₫ /$ Clinical Medicine,

\section{Dovepress}

Journal Citation Reports/Science Edition, EMBase, Scopus and the Elsevier Bibliographic databases. The manuscript management system is completely online and includes a very quick and fair peer-review system, which is all easy to use. Visit http://www.dovepress.com/ testimonials.php to read real quotes from published authors. 